\title{
DAMPAK PSIKOLOGIS SISWA PUTRI SAAT MENGALAMI MENSTRUASI DALAM PROSES BELAJAR PENDIDIKAN JASMANI SMA NEGERI 3 MEDAN
}

\author{
Indrakasih, Riyanti Khairiah
}

\begin{abstract}
ABSTRAK
Penelitian ini bertujuan untuk mengetahui dampak psikologis saat menstruasi yang dialami siswa putri dalam proses belajar pendidikan jasmani di kelas X SMA Negeri 3 Medan Tahun Ajaran 2014/2015. Keberhasilan suatu penelitian sangat erat hubungannya dengan metode yang di pergunakan dalam penelitian. Metode Penelitian yang digunakan adalah metode deskriptif dengan pendekatan melalui angket tertutup. Populasi dalam penelitian ini adalah seluruh siswa putri kelas X SMA Negeri 3 Medan yang berjumlah 328 siswi. Jumlah sampel yang diambil 25\% dari populasi setiap kelas yang telah disusun. Jumlah seluruh sampel 85 siswi teknik pengambilan sampel dengan menggunakan proporsional random sampling dan dilakukan dengan undian secara acak melalui gulungan kertas.

Hasil penelitian dari 85 sampel terdiri dari 2 indikator yang disusun berdasarkan teori menunjukkan bahwa hasil analisis data berdasarkan Kematangan Mental siswa putri $(67,54 \%)$ pada kategori tinggi. Berdasarkan Emosional siswa putri $(53,48 \%)$ pada kategori cukup/netral. Dengan demikian Dampak Psikologis Siswa Putri Saat Mengalami Menstruasi dalam Proses Belajar Pendidikan Jasmani SMA Negeri 3 Medan Tahun Ajaran 2014/2015 adali $60,04 \%$ dalam kategori cukup/netral.
\end{abstract}

\section{A. PENDAHULUAN}

Selama rentang kehidupan manusia, telah terjadi banyak pertumbuhan dan perkembangan dari mulai lahir sampai dengan meninggal dunia. Dari semua fase perkembangan manusia tersebut, salah satu yang penting dan paling menjadi pusat perhatian adalah masa remaja. Masa remaja yang dimaksud merupakan periode transisi antara masa anak-anak dan masa dewasa. Batasan usianya tidak di tentukan dengan jelas, sehingga banyak ahli yang berbeda dalam penentuan rentang usianya. Namun, secara umum dapat di katakan bahwa masa remaja berawal dari usia 12 sampai dengan akhir usia belasan ketika pertumbuhan fisik hampir lengkap. 
Peristiwa terpenting yang terjadi pada gadis remaja ialah datangnya menstruasi pertama kali, biasanya sekitar umur 10 sampai 16 tahun. Saat menstruasi pertama kali dinamakan menarche. Menarche dianggap sebagai tanda pubertas atau masa awal pematangan seksual. Dilihat dari kelakukan sehari - hari, wanita sangat berbeda sekali saat ia mengalami menstruasi. Khususnya pada siswa putri yang biasanya tampil ceria, memiliki stamina yang prima untuk melakukan kegiatan belajar pendidikan jasmani di sekolah. Tiba-tiba bisa menjadi lesu, malas dan tidak semangat untuk mengikuti pendidikan jasmani serta mudah tersinggung sepertinya memiliki beban di dalam dirinya.

Terlihat dalam prakteknya penjas, sebagian siswa putri terlihat malas melakukan gerakan dalam melakukan proses belajar pendidikan jasmani di lapangan. Alasan siswi tersebut sedang menstruasi, siswa putri tersebut takut noda darah jadi tembus dan meninggalkan bekas noda di roknya, sehingga siswa pu1 malu diketahui oleh siswa putra kalau dirinya sedang menstruasi.

\section{B. Pembahasan}

\section{Dampak Psikologis Remaja Putri}

\section{Hakikat Psikologis Remaja Putri}

Sebelum kita mengalami masa remaja kita akan melewati masa pubertas, masa pubertas berasal dari kata latin yang artinya tanda awal kedewasaan. Menurut Hurlock (1980:185) “ antara masa pubertas dan masa remaja terjadi tumpang tindih". Karena masa pubertas dimulai dari 1 atau 2 tahun terakhir masa kanak-kanak sampai dengan 1 atau 2 tahun masa remaja. Seperti skala dibawah ini

Gambar 1. Skala Masa Puber Perempuan

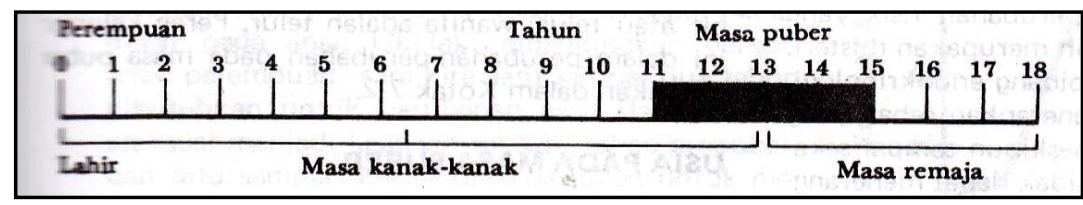


Menurut arti kata-kata psikologi berasal dari kata psyche yang berarti jiwa, dan logos artinya ilmu, jadi psikologi artinya ilmu jiwa. Dalam Kamus Kecil Bahasa Indonesia (1994:378) psikologis adalah sesuatu yang bersifat kejiwaan.

Didalam buku Hurlock (1980:206) mengatakan masa remaja atau adolescence berasal dari bahasa latin adolescere, yang artinya tumbuh menjadi dewasa. Istilah adolescence atau yang kita kenal dengan remaja mempunyai arti yang lebih luas yaitu, mencakup kematangan mental, emosional, sosial dan fisik.

Tabel 1.

Psikologi Perkembangan Remaja Putri

\begin{tabular}{|l|l|}
\hline Psikologis Remaja & \multicolumn{1}{|c|}{ Mencakup } \\
\hline Kematangan Mental & - Pikiran \\
& $\begin{array}{l}\text { - Batin / jiwa } \\
- \text { Sifat }\end{array}$ \\
\hline Emosional & - Keyakinan hidup \\
\hline Sosial & - Penuh emosi \\
\hline Fisik & $\begin{array}{l}\text { Hubungan dengan } \\
\text { masyarakat / lingkungan }\end{array}$ \\
\hline
\end{tabular}

Sedangkan psikologis remaja dalam buku Hurlock (1980:206) menurut pandangan

Piaget (121) mengatakan :

" Secara psikologis, masa remaja adalah usia dimana individu berintegrasi dengan masyarakat dewasa, usia dimana anak tidak lagi merasa di bawah tingkat orang - orang yang lebih tua melainkan berada dalam tingkat yang sama, sekurang - kurangnya dalam masalah hak. Intergrasi dalam masyarakat (dewasa) mempunyai banyak aspek afektif, kurang lebih berhubungan dengan masa puber. Termasuk juga perubahan intelektual yang mencolok. Transformasi intelektual yang khas dari cara berpikir remaja ini memungkinkannya untuk mencapai intergrasi dalam hubungan sosial orang dewasa, yang kenyataannya merupakan ciri khas yang umum dari priode perkembangan ini ". 
Salah satu pakar psikologi perkembangan Hurlock (1980:206) menyatakan bahwa, "masa remaja ini di mulai pada saat anak mulai matang secara seksual dan berakhir pada saat ia mencapai usia dewasa secara hukum”. Masa remaja di bagi menjadi dua bagian masa remaja awal dan masa remaja akhir. Masa remaja awal di mulai pada saat anak-anak mulai matang secara seksual yaitu pada usia 13 sampai 17 tahun, sedangkan masa remaja akhir meliputi periode setelahnya sampai dengan 19 tahun, yaitu usia di mana seseorang dinyatakan dewasa secara umum.

\section{Pengertian Dampak Psikologis}

Dalam Kamus Kecil Bahasa Indonesia (1994:117) dampak adalah pengaruh yang kuat sehingga menimbulkan akibat (baik negatif maupun positif), dan di dalam Kamus Kecil Bahasa Indonesia (1994:378) psikologis adalah bersifat kejiwaan. Dampak psikologis dapat diartikan sebagai pengaruh yang di lihat, atau sesuatu yang akan terjadi di dalam diri seseorang baik itu hal yang positif maupun negatif. Dari dampak psikologis ini kita dapat mempelajari bagaimana pengaruh psikologis pada penampilan fisik dan psikisnya dalam memahami keterlibatan prilaku yang ada di dalam dirinya atau jiwa seseorang, dan bagaimana cara dirinya melakukan kegiatan sehari - hari yang mempengaruhi perkembangan psikis maupun kesehatan psikisnya.

\section{Psikologis Siswa Putri Dalam Proses Belajar Pendidikan Jasmani}

\section{a. Hakikat Pendidikan Jasmani}

Dalam Kamus Bahasa Indonesia (1991:232), Pendidikan berasal dari kata "didik", Lalu kata ini mendapat awalan kata "me" sehingga menjadi "mendidik" artinya memelihara dan memberi latihan. Dalam memelihara dan memberi latihan 
diperlukan adanya ajaran, tuntutan dan pimpinan mengenai akhlak dan kecerdasan pikiran.

\section{b.Tujuan Pendidikan Jasmani}

Tujuan pendidikan sejati tidaklah hanya mengisi ruang-ruang imajinasi dan intelektual anak, mengasah kepekaan sosialnya, ataupun memperkenalkan mereka pada aspek kecerdasan emosi, tapi lebih kepada mempersiapkan mereka untuk mengenal Tuhan dan sesama manusia. Tujuan pendidikan secara umum dapat dilihat pada:

"TAP MPR NO II/MPR/1993 Tujuan Pendidikan nasional yaitu Meningkatkan kualitas manusia Indonesia, yaitu manusia yang beriman dan bertakwa terhadap Tuhan Yang Maha Esa, berbudi pekerti luhur, berkepribadian, mandiri, maju, tangguh, cerdas, kreatif, terampil, berdisiplin, beretos kerja profesional serta sehat jasmani dan rohani". (Www.AsianBrain.com).

Dalam buku Abdullah, Menurut Barrow (1977:25) tujuan pendidikan jasmani yaitu perkembangan optimal dari individu yang utuh berkemampuan menyesuaikan diri secara jasmaniah, sosial dan mental, melalui pelajaran yang terpimpin dan partisipasi dalam olahraga yang dipilih, senam irama, dan senam yang dilaksanakan sesuai dengan standar sosial dan kesehatan.

\section{c. Psikologis Siswa Putri Saat Pendidikan Jasmani}

Apabila dihubungkan dengan psikologis siswi yang sedang belajar, khususnya siswa yang sedang melakukan kegiatan pendidikan jasmani, kita dapat mengamati perilaku siswa yang di perlihatkan oleh seseorang ketika ia ikut kegiatan jasmani olahraga disekolahnya. Dimana kita ketahui dengan berolahraga tubuh kita menjadi sehat dan bugar serta senang setelah berolahraga. Artinya, pada saat berolahraga siswa memiliki pengaruh tertentu terhadap kondisi fisik 
maupun psikisnya dalam hal kualitas kepribadiannya. Karena berolahraga, maka kondisi psikis siswa akan berdampak positif dan selanjutnya akan membentuk ciri-ciri kepribadian atau gambaran kepribadian yang positif pula.

Tetapi ada sebagian siswa, khususnya siswa putri yang biasanya tampil ceria dan memiliki stamina yang prima untuk melakukan kegiatan belajar pendidikan jasmani di sekolah, tiba-tiba bisa menjadi lesu, malas dan mudah tersinggung sepertinya tidak semangat dan ada beban atau ketakutan di dalam dirinya untuk mengikuti pendidikan jasmani.

\section{Dampak Psikologis Saat Menstruasi}

\section{a. Hakikat Menstruasi}

Menurut Prawiroharjo (2008:103) menstruasi ialah pendarahan secara periodik dan siklik dari uterus disertai pelepasan endometrium. Menurut Derek (2005:26) Peristiwa terpenting bagi seorang putri yaitu datangnya menstruasi pertama kali, biasanya sekitar umur 10 sampai 16 tahun. Saat menstruasi pertama kali disebut menarche. Menarche dianggap sebagai tanda pubertas atau masa awal pematangan seksual.

\section{b. Siklus Menstruasi}

Di dalam buku setiap wanita, Derek (2005:29) mengatakan "ketika haid rahim menangis karena pembuahan tidak kunjung terjadi. Pendarahan akibat runtuhnya dinding lapisan dalam rahim adalah serangkaian peristiwa saling berkaitan, yang bertujuan mempersiapkan rahim menampung sel telur yang di buahi”. 
Bila tidak terjadi kehamilan, maka dinding lapisan yang sudah dipersiapkan menjadi mengelupas, karena menstruasi merupakan keluarnya darah dari dalam rahim yang terjadi kerena sel telur tidak dibuahi. Sehingga siklus menstruasi yang baru pun dimulai.

Untuk lebih jelasnya dapat dilihat dalam gambar dibawah ini:

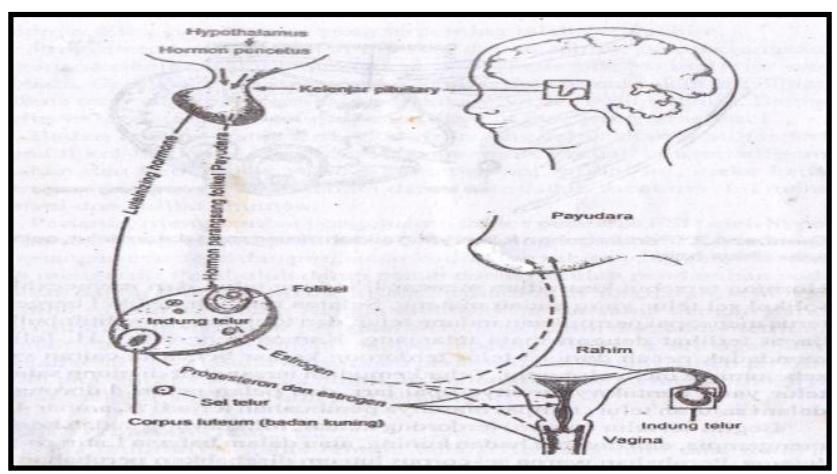

Gambar 2. Pengendalian Siklus Menstruasi

Sedangkan menurut Nita dalam jurnal remaja putri dan siklus menstruasi :

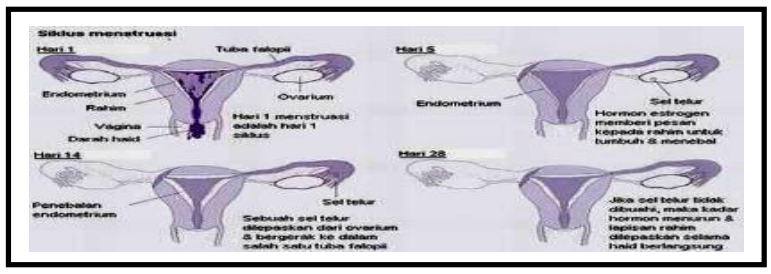

Gambar 3. Siklus Menstruasi

1. Hari ke-5 dari siklus menstruasi, endometrium mulai tumbuh dan menebal sebagai persiapan terhadap kemungkinan terjadinya kehamilan

2. Sekitar hari ke-14 terjadi pelepasan telur dari ovarium disebut ovulasi. Sel telur ini masuk ke dalam salah satu tuba falopii. Di dalam tuba falopii dapat terjadi pembuahan oleh sperma. Jika terjadi pembuahan, sel telur akan masuk ke dalam rahim dan tumbuh menjadi janin sehingga terjadilah kehamilan.

3. Pada sekitar hari ke-28, jika tidak terjadi pembuahan, maka endometrium akan dilepaskan dan terjadilah perdarahan atau disebut sebagai siklus menstruasi. Siklus dapat berlangsung selama 3-5 hari, terkadang sampai 7 hari. Proses pertumbuhan dan penebalan endometrium kemudian dimulai lagi pada siklus berikutnya (http://www.nita-medicastore.com) 


\section{c. Dampak Psikologis Saat Menstruasi}

Dampak psikologis secara umum terjadi pada wanita yang mengalami siklus menstruasi sekitar menjelang dan sesudah menstruasi. Sebagian remaja putri diliputi suasana yang tidak menentu dan juga perasaan yang kurang nyaman atau terasa sakit di sekitar bawah pusar. Hal ini bisa saja membuat seorang perempuan menjadi cepat lelah dan mudah tersinggung perasaannya. Dampak psikologis menstruasi ini muncul dalam bentuk tingkah laku berupa perasaan lelah, mudah teriritasi, cemas, depresi, emosi labil, insomnia, nafsu makan meningkat dan kesulitan bekerja efektif.

\section{METODOLOGI PENELITIAN}

\section{Populasi dan Sampel}

\section{Populasi}

Populasi merupakan objek yang akan di teliti sesuai dengan ketentuanketentuan yang dirumuskan pada pokok masalah. Menurut Arikunto (2006:130) menyatakan bahwa, "Populasi adalah subjek penelitian". Sehingga dalam penelitian ini yang menjadi populasi adalah seluruh siswa putri kelas X SMA Negeri 3 Medan, di karenakan jumlahnya lebih banyak siswa putri, yaitu sebanyak 328 siswa yang terdiri atas sebelas kelas, sementara kelas XI dan XII hanya sembilan kelas. Siswa kelas $\mathrm{X}$ baru saja melewati masa puber dan baru memulai masa remaja.

\section{Sampel}

Sampel merupakan orang yang menjadi sumber data yang terdiri dari sebagian populasi yang dipandang dapat mewakili populasi. Sebagaimana Arikunto (2006:107) menyatakan bahwa, “ apabila jumlah subjek kurang dari 100 
orang, lebih baik diambil semuanya, sehingga penelitiannya merupakan penelitian populasi. Selanjutan jika subjeknya besar maka dapat diambil antara $10 \%-15 \%$ atau 20\%-25\% atau lebih. Dalam hal ini jumlah sampel yang diambil $25 \%$ dari populasi setiap kelas, yaitu:

TABEL 2

Jumlah Siswa Putri Kelas X

\begin{tabular}{|c|c|c|}
\hline Kelas & Jumlah & \multicolumn{1}{|c|}{ 25\% } \\
\hline X-1 & 27 & $\frac{25}{100} \times 27=6,75$ dibulatkan menjadi 7 \\
X-2 & 28 & $\frac{25}{100} \times 28=7$ \\
X-3 & 27 & $\frac{25}{100} \times 27=6,75$ dibulatkan menjadi 7 \\
X-4 & 30 & $\frac{25}{100} \times 30=7,5$ dibulatkan menjadi 8 \\
X-5 & 30 & $\frac{25}{100} \times 30=7,5$ dibulatkan menjadi 8 \\
X-6 & 30 & $\frac{25}{100} \times 30=7,5$ dibulatkan menjadi 8 \\
X-7 & 32 & $\frac{25}{100} \times 32=\mathbf{8}$ \\
X-8 & 34 & $\frac{25}{100} \times 34=8,5$ dibulatkan menjadi 9 \\
X-9 & 30 & $\frac{25}{100} \times 30=7,5$ dibulatkan menjadi 8 \\
X-10 & 32 & $\frac{25}{100} \times 32=\mathbf{8}$ \\
X-11 & 28 & $\frac{25}{100} \times 28=7$ \\
\hline Jumlah & $\mathbf{3 2 8}$ & dilakukan $\quad$ melalui Proporsional Random
\end{tabular}

Sampling

\section{Metode Penelitian}

Metode yang di pergunakan dalam penelitian ini metode yang digunakan adalah metode deskriptif dengan pendekatan melalui angket tertutup. Arikunto 
(2006:310) menyatakan, "penelitian deskriptif maksudnya hanya menggambarkan apa adanya tentang suatu variable gejala atau keadaan".

\section{Instrumen Penelitian}

Instrumen penelitian yang digunakan dalam penelitian ini adalah angket tertutup yang artinya jawabannya sudah pasti. Angket ini berisikan pertanyaan yang mengacu untuk mengetahui seberapa besar dampak psikologis siswa putri saat mengalami menstruasi dalam belajar pendidikan jasmani pada di SMU Negeri 3 Medan.

Tabel 3

Indikator Angket

\begin{tabular}{|c|c|c|c|c|}
\hline \multirow{2}{*}{ Variabel } & \multirow{2}{*}{ Indikator } & \multirow{2}{*}{ Sub Indikator } & \multicolumn{2}{|c|}{ Nomer Soal Pengaruh } \\
\hline & & & + & - \\
\hline \multirow{2}{*}{$\begin{array}{l}\text { Dampak Psikolo- } \\
\text { gis Siswa Putri } \\
\text { saat Mengalami } \\
\text { Menstruasi dalam } \\
\text { Proses Belajar } \\
\text { Pend. Jasmani }\end{array}$} & $\begin{array}{c}\text { Kematangan } \\
\text { Mental }\end{array}$ & $\begin{array}{l}\text { - Pikiran } \\
\text { - Batin / jiwa } \\
\text { - Sifat } \\
\text { - Keyakinan } \\
\text { hidup }\end{array}$ & $\begin{array}{l}\text { 1. Percaya diri } \\
\text { 2. Tenang } \\
\text { 3. Nyaman } \\
\text { 4. Konsentrasi } \\
\text { 5. Tampil prima } \\
\text { 6. Sehat }\end{array}$ & $\begin{array}{l}\text { 7. Stress } \\
\text { 8. Ragu } \\
\text { 9. Murung } \\
\text { 10. Pelupa } \\
\text { 11. Bingung } \\
\text { 12. Banyak pikiran } \\
\text { 13. Tekan batin } \\
\text { 14. Pesimis }\end{array}$ \\
\hline & Emosional & $\begin{array}{l}\text { - Luapan pera- } \\
\text { saan } \\
\text { - Penuh emosi }\end{array}$ & $\begin{array}{l}\text { 15. Senang } \\
\text { 16. Semangat } \\
\text { 17. Suka } \\
\text { 18. Ingin Diperha- } \\
\text { tikan } \\
\text { 19. Memperhatikan } \\
\text { penampilan }\end{array}$ & $\begin{array}{l}\text { 20. Cemburu } \\
\text { 21. Marah } \\
\text { 22. Mudah tersingung } \\
\text { 23. Sedih } \\
\text { 24. Risih } \\
\text { 25. Takut } \\
\text { 26. Mencari alasan } \\
\text { 27. Perasaan sendiri } \\
\text { 28. Malu } \\
\text { 29. Lesu / lelah } \\
\text { 30. Malas }\end{array}$ \\
\hline
\end{tabular}

Adapun pembuatan angket nantinya berdasarkan kriteria, yaitu:

1. Kriteria pengaruh positif, dengan memilih : 


$$
\begin{array}{ll}
\text { Jawaban } \mathrm{A} \rightarrow \text { Ya, sangat setuju } & : \text { skor } 5 \\
\text { Jawaban } \mathrm{B} \rightarrow \text { Ya, setuju } & : \text { skor } 4 \\
\text { Jawaban } \mathrm{C} \rightarrow \text { Kadang-kadang } & : \text { skor } 3 \\
\text { Jawaban D } \rightarrow \text { Tidak setuju } & : \text { skor } 2 \\
\text { Jawaban E } \rightarrow \text { Tidak setuju sekali } & : \text { skor } 1
\end{array}
$$

2. Kriteria pengaruh negatif, dengan memilih :

$$
\begin{array}{ll}
\text { Jawaban } \mathrm{A} \rightarrow \text { Ya, sangat setuju } & : \text { skor } 1 \\
\text { Jawaban } \mathrm{B} \rightarrow \text { Ya, setuju } & : \text { skor } 2 \\
\text { Jawaban } \mathrm{C} \rightarrow \text { Kadang-kadang } & : \text { skor } 3 \\
\text { Jawaban D } \rightarrow \text { Tidak setuju } & : \text { skor } 4 \\
\text { Jawaban E } \rightarrow \text { Tidak setuju sekali } & : \text { skor } 5
\end{array}
$$

\section{Hasil Penelitian}

Berdasarkan perhitungan hasil data penelitian Dampak Psikologis Siswa Putri Dalam Proses Belajar Pendidikan Jasmani SMU Negeri 3 Medan Tahun Ajaran 2014/2015 maka diperoleh persentase dari setiap psikologis perkembangan remaja putri menurut Harlock adalah sebagai berikut :

1. Berdasarkan Kematangan Mental

a. Dampak positif, data mentah yang diperoleh adalah 1832, dan data seharusnya 2550.

b. Dampak negatif, data mentah yang diperoleh adalah 2187 , dan data seharusnya 3400 .

Jadi berdasarkan kematangan mentalnya seluruh data mentah yang diperoleh adalah 4019, dan data seharusnya 5950 dengan persentase 67,54\%. Termasuk kategori tinggi. 
2. Berdasarkan Emosionalnya

a. Dampak positif, data mentah yang diperoleh adalah 1270, dan data seharusnya 2125.

b. Dampak negatif, data mentah yang diperoleh dalah 2367, dan data seharusnya 4675 .

Jadi berdasarkan emosionalnya, seluruh data mentah yang diperoleh adalah 3637 , dan data seharusnya 6800 dengan persentase $53,48 \%$. Termasuk kategori cukup/netral.

Berdasarkan Indikator Dampak Psikologis Remaja Putri maka dari 30 item angket penelitian yang disebarkan, secara keseluruhan data mentah yang diperoleh adalah 7656 dan data seharusnya 12750 dengan persentase 60,04\% termasuk kategori cukup/ netral. Untuk lebih jelasnya dapat dilihat pada tabel 5 dibawah ini

Tabel 5.
Persentase Dampak Psikologis Siswa Putri saat Mengalami Menstruasi dalam Proses Belajar Pendidikan Jasmani SMA Negeri 3 Medan Tahun Ajaran 2014/2015

\begin{tabular}{|c|c|c|c|c|c|c|c|}
\hline No & Item & Indikator & $\begin{array}{c}\text { Data } \\
\text { Mentah }\end{array}$ & $\begin{array}{c}\text { Data } \\
\text { Seharusnya }\end{array}$ & $\%$ & Persentase & Kategori \\
\hline 1 & 1 s/d 14 & Kematangan Mental & 4019 & 5950 & 100 & $67,54 \%$ & Tinggi \\
\hline 2 & 15 s/d 30 & Emosional & 3637 & 6800 & 100 & $53,48 \%$ & Sedang / Netral \\
\hline \multicolumn{2}{|c|}{ Jumlah } & $\mathbf{7 6 5 6}$ & $\mathbf{1 2 7 5 0}$ & $\mathbf{1 0 0}$ & $\mathbf{6 0 , 0 4 \%}$ & Cukup / Netral \\
\hline
\end{tabular}

Berdasarkan tabel diatas, persentase Dampak Psikologis Siswa Putri saat Mengalami Menstruasi dalam Proses Belajar Pendidikan Jasmani SMA Negeri 3 Medan Tahun Ajaran 2014/2015 dapat dilihat pada diagram batang dibawah ini: 


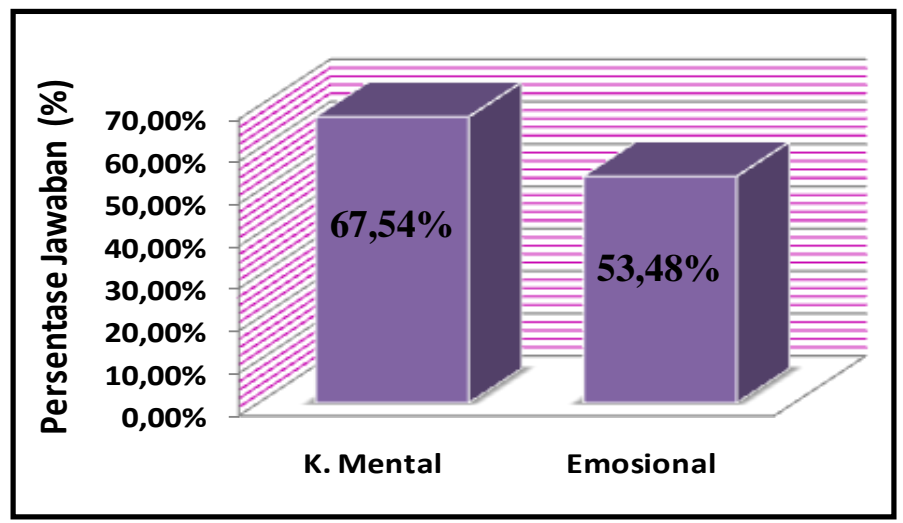

\section{Gambar 4. Diagram Batang Indikator Psikologis Remaja Putri Saat Mentruasi Dalam Proses Belajar Pendidikan Jasmani}

\section{Kesimpulan}

Berdasarkan hasil analisis data dan pembahasan hasil penelitian dari data Dampak Psikologis Siswa Putri saat Mengalami Menstruasi dalam Poses Belajar Pendidikan Jasmani SMA Negeri 3 Medan Tahun Ajaran 2014/2015, dapat disimpulkan bahwa nilai persentase secara keseluruhan sebesar 60,04\%. Nilai tersebut termasuk dalam kategori cukup/ netral, artinya saat mengalami menstruasi psikologis siswa putri berdampak stabil tidak tinggi dan tidak rendah (netral), karena manfaat penjas salah satunya adalah untuk keseimbangan psikologis.

Pada saat menstruasi hormone dalam tubuh tidak seimbang sehingga wanita kerap sekali mengalami gangguan psikologis. Jadi dengan siswi mengikuti pandidikan jasmani maka membantu hormone yang tidak seimbang menjadi seimbang dan siklus menstruasi menjadi lancar di dalam tubuh. 


\section{DAFTAR PUSTAKA}

Abdullah, Arma. (1994). Dasar - Dasar Pendidikan Jasmani. Jakarta,

\section{B3PTKSM}

Arikunto, Suharsimi. (2006). Prosedur Penelitian dan Menejemen Penelitian. Jakarta, Rineka Cipta.

Asian Brain. Memahami Tujuan Pendidikan. Www.asianbrain.com

Boyke. PMS. Http://jurnalnasional.com

Kartini, Kartono. (1995). Psikologi Wanita Mengenal Gadis Remaja dan Wanita Dewasa 1. Mandar, Bandung.

Mulyono. (1994). Persepsi Siswa Putri Kelas II Terhadap Aktivitas Penjas Pada Saat Menstruasi di MAN 2 Tanjung Balai. Medan, FIK-UNIMED.

Ndong, Kamtomo. (1986). Psikologi Olahraga. Jakarta. Pelagan.

Prawirohardjo, Sarwono. (2008). Ilmu Kandungan. Jakarta, Bina Pustaka.

Purnamasari. PMS banyak buat Wanita Aneh danTak Wajar.

Http://puripurnamasari. wordpress.com.

Purwanto, Ngalim (1992). Psikologi Pendidikan. Bandung, Remaja Rosdakarya.

Singarimbun, Marsi. (1984). Metodologi Penelitian Surve. Jakarta. PT.Pertja.

Singgih, Gunarsa (2008). Psikologi Olahraga Prestasi. Jakarta, BPK Gunung

Mulia.

Sudjana (2002). Metode Statistika. Tarsito, Bandung. 